\title{
MOLECULAR PHYLOGENY OF THE KIDNEY-PARASITIC SPHAEROSPORA RENICOLA FROM COMMON CARP (CYPRINUS CARPIO) AND SPHAEROSPORA SP. FROM GOLDFISH (CARASSIUS AURATUS AURATUS)
}

\author{
Edit ESZTERBAUER ${ }^{*}$ and CS. SZÉKELY \\ Veterinary Medical Research Institute, Hungarian Academy of Sciences, \\ H-1581 Budapest, P.O. Box 18, Hungary
}

(Received June 23, 2004; accepted September 1, 2004)

\begin{abstract}
The genetic relatedness of two kidney-parasitic Sphaerospora species was studied. Although $S$. renicola, the causative agent of swimbladder inflammation of common carp fingerlings (Cyprinus carpio), and Sphaerospora sp. originating from goldfish (Carassius auratus auratus) were indistinguishable on the basis of spore morphology, they were found to be genetically different as their $18 \mathrm{~S}$ rDNA sequences shared only $71.9 \%$ identical nucleotides. In the phylogenetic trees, Sphaerospora sp. from goldfish grouped with Myxidium truttae (AJ582061) within the clade of the coelozoic freshwater species. Sphaerospora renicola clustered with $S$. molnari (AF378345) within the group of myxosporeans histozoic in gills. The topology of the six Sphaerospora species on the phylogenetic trees implied that myxospore morphology does not correlate with the genetic relationships, and the genus seems to be polyphyletic.
\end{abstract}

Key words: Myxosporeans, Sphaerospora spp., carp, goldfish, kidney tubules, swimbladder inflammation, $18 \mathrm{~S}$ rDNA, molecular phylogeny

About 50 species of myxosporeans in the genus Sphaerospora have been described from several freshwater and marine fish (Lom and Dyková, 1992). The general morphological features in this genus are spherical or subspherical spore shape, prominent sutural ridge and subspherical, sometimes pyriform polar capsules. Most of the species are coelozoic, developing mature myxospores in the renal tubules.

The best known freshwater species is Sphaerospora renicola Dyková and Lom, 1982, which is widely distributed in cultures of common carp (Cyprinus carpio). The extrasporogonic developmental stages emerging seasonally in blood cause swimbladder inflammation (SBI) in carp fingerlings. A number of reports have been published about the complex developmental cycle of this parasite since the 1980s. The aetiology of parasitic SBI was first suggested by Molnár (1980b), who hypothesised that the developmental stages found in the blood by

*Corresponding author; E-mail: eedit@vmri.hu; Fax: +36 (1) 4674076 
Csaba (1976) and the proliferating stages detected in the swimbladder by Kovács-Gayer et al. (1982) and Körting (1982) might be the early stages of the kidney-parasitic $S$. renicola. Several authors have also studied the pathogenicity in detail (Molnár, 1980a; Odening, 1987; Dyková and Lom, 1988). Al-Samman et al. (2003) reported that swimbladder changes were accompanied by reno-, hepato- and splenomegaly in carp fry suffering from SBI.

Until recently, five Sphaerospora species have been studied genetically on DNA level. The sequence of the 18S ribosomal RNA gene (18S rDNA) of kidney-parasitic S. oncorhynchi (AF201373, Kent et al., 2001) and S. truttae (AJ581915, Holzer et al., 2003a) have been studied from salmonids, while $S$. dicentrarchi (AY278564) originating from sea bass (Dicentrarchus labrax) has been described genetically by Caffara et al. (unpublished). The partial 18S rDNA sequence of S. elegans (AJ609590) from stickleback (Gasterosteus aculeatus) has also been submitted to GenBank by Holzer et al. (2003b). The only species parasitising cyprinids that has been examined to date is $S$. molnari (AF378345) collected from the gills of goldfish (Carassius auratus) in Japan (Kent et al., 2001).

In the present paper, the partial $18 \mathrm{~S}$ rDNA sequence of two kidneyparasitic Sphaerospora species, S. renicola from common carp and Sphaerospora sp. from goldfish (Carassius auratus auratus) was determined in order to estimate their phylogenetic positions among other myxosporeans.

\section{Materials and methods}

Myxospores of two Sphaerospora species were collected from cyprinids in Hungary (Table 1). After collection and transportation to the laboratory, several dozens of common carp fingerlings and seven goldfish were sacrificed by an overdose of the anaesthetic MS 222, followed by severance of the spinal cord. Squash preparations of gills, kidney, swimbladder and the rete mirabile in the eye were examined for the presence of mature spores and blood stages of Sphaerospora. Mature spores were measured and morphologically identified. Digital pictures of the myxospores were also taken with an Olympus DP 10 camera. Kidney samples collected were preserved deep frozen in 1.5-ml Eppendorf tubes until further use.

DNA extraction from the samples was performed by different methods. Samples containing mature myxospores (samples no. 1 and 2) were homogenised in distilled water and then spores were separated from the host cells using a twophase system of $4.8 \%$ dextran and $3.76 \%$ polyethylene glycol (PEG, MW 6000) as described by Holzer et al. (2003a). As this separation method is based on the surface differences between mature myxospore and host cell, it is not efficient for the separation of blood stages and immature myxospores. The PEG phase containing the spores was washed twice with distilled water and centrifuged at 
$2000 \mathrm{~g}$ for $10 \mathrm{~min}$. The spore pellet was suspended in $500 \mu \mathrm{l}$ lysis buffer $(100 \mathrm{mM} \mathrm{NaCl}, 10 \mathrm{mM}$ Tris, $10 \mathrm{mM}$ EDTA, $0.2 \%$ SDS, and $0.4 \mathrm{mg} / \mathrm{ml}$ proteinase $\mathrm{K}$ ) and incubated at $55^{\circ} \mathrm{C}$ for 3-4 h. DNA was extracted using the Miniprep Express Matrix (BIO 101) as described previously by Eszterbauer (2004). Samples containing immature myxospores were homogenised in distilled water and digested in lysis buffer containing proteinase $\mathrm{K}$ (as mentioned above) overnight. DNA extraction was carried out using phenol and chloroform followed by precipitation with sodium acetate in ethanol (Molnár et al., 2002). DNA was resuspended in MilliQ-purified water. DNA content was estimated by electrophoresis of known amount of $\lambda$ phage DNA cut with PstI.

Table 1

Sphaerospora species examined. Samples were collected from different fish farms in Hungary

\begin{tabular}{|c|c|c|c|c|c|c|}
\hline Species & Fish host & Locality & $\begin{array}{l}\text { Sampling } \\
\text { date }\end{array}$ & $\begin{array}{l}\text { Host } \\
\text { organ }\end{array}$ & $\begin{array}{c}\text { Develop } \\
\text { mental } \\
\text { stage }\end{array}$ & $\begin{array}{c}\text { Sample } \\
\text { no. }\end{array}$ \\
\hline \multirow[t]{3}{*}{$\begin{array}{l}\text { S. renicola } \\
\text { Dyková and } \\
\text { Lom, } 1982\end{array}$} & $\begin{array}{l}\text { Common } \\
\text { carp } \\
\text { (Cyprinus } \\
\text { carpio) }\end{array}$ & Százhalombatta & $29 / 08 / 2002$ & $\begin{array}{l}\text { kidney } \\
\text { tubules }\end{array}$ & $\begin{array}{l}\text { mature } \\
\text { spores }\end{array}$ & 1 \\
\hline & & Százhalombatta & $15 / 08 / 2003$ & $\begin{array}{l}\text { kidney } \\
\text { tubules }\end{array}$ & $\begin{array}{l}\text { mostly } \\
\text { mature } \\
\text { spores }\end{array}$ & 2 \\
\hline & & Hortobágy & $19 / 07 / 2002$ & $\begin{array}{l}\text { kidney } \\
\text { tubules }\end{array}$ & $\begin{array}{c}\text { immature } \\
\text { spores }\end{array}$ & 3 \\
\hline \multirow[t]{2}{*}{ S. sp. } & $\begin{array}{c}\text { Goldfish } \\
\text { (Carassius } \\
\text { auratus } \\
\text { auratus) }\end{array}$ & Százhalombatta & $24 / 02 / 2004$ & $\begin{array}{l}\text { kidney } \\
\text { tubules }\end{array}$ & $\begin{array}{l}\text { mature and } \\
\text { immature } \\
\text { spores }\end{array}$ & 4 \\
\hline & & Százhalombatta & $25 / 02 / 2004$ & $\begin{array}{l}\text { kidney } \\
\text { tubules }\end{array}$ & $\begin{array}{l}\text { mature and } \\
\text { immature } \\
\text { spores }\end{array}$ & 5 \\
\hline
\end{tabular}

For PCR amplification of the 18S rDNA of Sphaerospora species examined, a primer pair named SphF-SphR was designed on the basis of the alignment of Sphaerospora sequences submitted to GenBank by February 2003. Primer sequences and their references are summarised in Table 2. The total volume of PCR was $50 \mu 1$ that contained 10-50 ng extracted DNA, $1 \times$ Taq PCR reaction buffer (MBI Fermentas), $1.25 \mathrm{mM} \mathrm{MgCl}_{2}, 0.2 \mathrm{mM}$ dNTP mix (Sigma), 50 pmol of each primer and 2 units of Taq DNA Polymerase (MBI Fermentas). MJ Research PTC-200 and a Biometra T1 thermocycles were used for amplifi- 
cation. Amplification conditions were $95{ }^{\circ} \mathrm{C}$ for $50 \mathrm{sec}, 56^{\circ} \mathrm{C}$ for $50 \mathrm{sec}$ and $72{ }^{\circ} \mathrm{C}$ for $80 \mathrm{sec}$ for $35 \mathrm{cycles}$, with a terminal extension at $72^{\circ} \mathrm{C}$ for $7 \mathrm{~min}$. PCR products were electrophoresed in $1.0 \%$ agarose gel and purified with Geneclean III Kit (Bio 101).

Except $S$. renicola sample no. 1, PCR fragments purified were cloned into pGEM-T vector with pGEM-T Vector System I (Promega) following the manufacturer's manual. Positive clones were selected using the blue-white colour screening method. Positive clones were sequenced with universal forward primer.

The PCR product of sample no. 1 and positive clones were then sequenced in both directions with six primers listed in Table 2 using the Applied Biosystems (ABI) BigDye Terminator v3.1 Cycle Sequencing Kit with an ABI 3100 Genetic Analyzer automated DNA sequencer (Applied Biosystems). Only sample no. 1 was sequenced directly. For sequence assembling, the STADEN Sequence Analysis Package version 2001.0 (Staden, 1996) was used.

Table 2

Primers used for PCR and/or sequencing

\begin{tabular}{lll}
\hline Name & \multicolumn{1}{c}{ Sequence } & \multicolumn{1}{c}{ Reference } \\
\hline SphF & 5'-ACT CGT TGG TAA GGT AGT GGC T-3' & Present study \\
SphR & 5'-GTT ACC ATT GTA GCG CGC GT-3' & Present study \\
MB5r & 5'-ACC GCT CCT GTT AAT CAT CAC C-3' & Eszterbauer, 2004 \\
MB3f & 5'-GAT GAT TAA CAG GAG CGG TTG G-3' & Eszterbauer, 2004 \\
MC5 & 5'-CCT GAG AAA CGG CTA CCA CAT CCA-3' & Molnár et al., 2002 \\
MC3 & 5'-GAT TAG CCT GAC AGA TCA CTC CAC GA-3' & Molnár et al., 2002 \\
\hline
\end{tabular}

Nucleotide sequences were aligned with the MultAlin program (Corpet, 1988). The alignment was corrected manually using the GeneDoc sequence alignment editor program. Ambiguously aligned regions and gaps longer than 5 nucleotides were excluded. Phylogenetic calculations were performed with PHYLIP v3.6a (Felsenstein, 1997). The data were analysed with maximum likelihood (DNAML with transversion/transition ratio 1:1, 1:2 or 1:3, empirical base frequencies, one rate class for nucleotide substitution and global re-arrangements) and distance matrix analysis (DNADIST using Kimura-2 parameter followed by FITCH with global re-arrangements). Clade support was assessed with bootstrapping (100 replicates for maximum likelihood and 1000 replicates for distance matrix method). Polypodium hydriforme was chosen as outgroup. 


\section{Results}

During the morphological examination of fish kidneys collected for molecular study, only Sphaerospora species were identified and no other myxosporeans were observed in squash preparations. In carp kidney samples, the shape and size of mature myxospores found in renal tubules were identical with those of $S$. renicola described by Dyková and Lom (1982). The myxospores found in the kidney tubules of goldfish also showed very similar body shape and size, and were morphologically indistinguishable from S. renicola (Fig. 1).

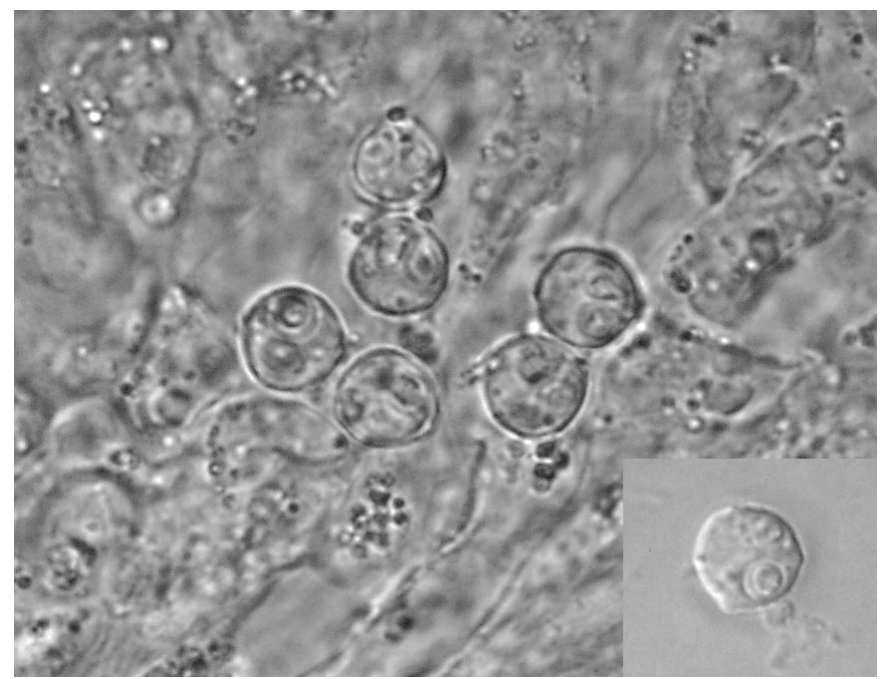

Fig. 1. Myxospores of Sphaerospora sp. from renal tubules of goldfish (Carassius auratus aura$t u s)$. Squash preparation. The scale bar is $10 \mu \mathrm{m}$

The SphF-SphR primers successfully amplified approx. $1400 \mathrm{bp}$ fragments of $18 \mathrm{~S}$ rDNA from every sample. The $1413 \mathrm{bp}$ sequence of $S$. renicola (AY735410) and the 1349 bp long sequence of Sphaerospora sp. (AY735411) from goldfish were deposited to GenBank. In the case of sample no. 3, one of the clones gave different sequence. With BLAST search, this clone was determined as an $18 \mathrm{~S}$ rDNA sequence belonging to myxosporeans, but it was not identical with any species available in GenBank. The most similar species was Myxobolus pavlovskii (AF507973), although their genetic similarity was only $86.5 \%$. The sequences of cloned fragments of S. renicola were generally $100 \%$ identical, except for three out of the eleven clones, where $0.07-0.21 \%$ differences at different positions were observed among sequences. In the case of Sphaerospora sp., only six clones were sequenced, and $0.07-0.14 \%$ nucleotide differences also occurred in two clones. 


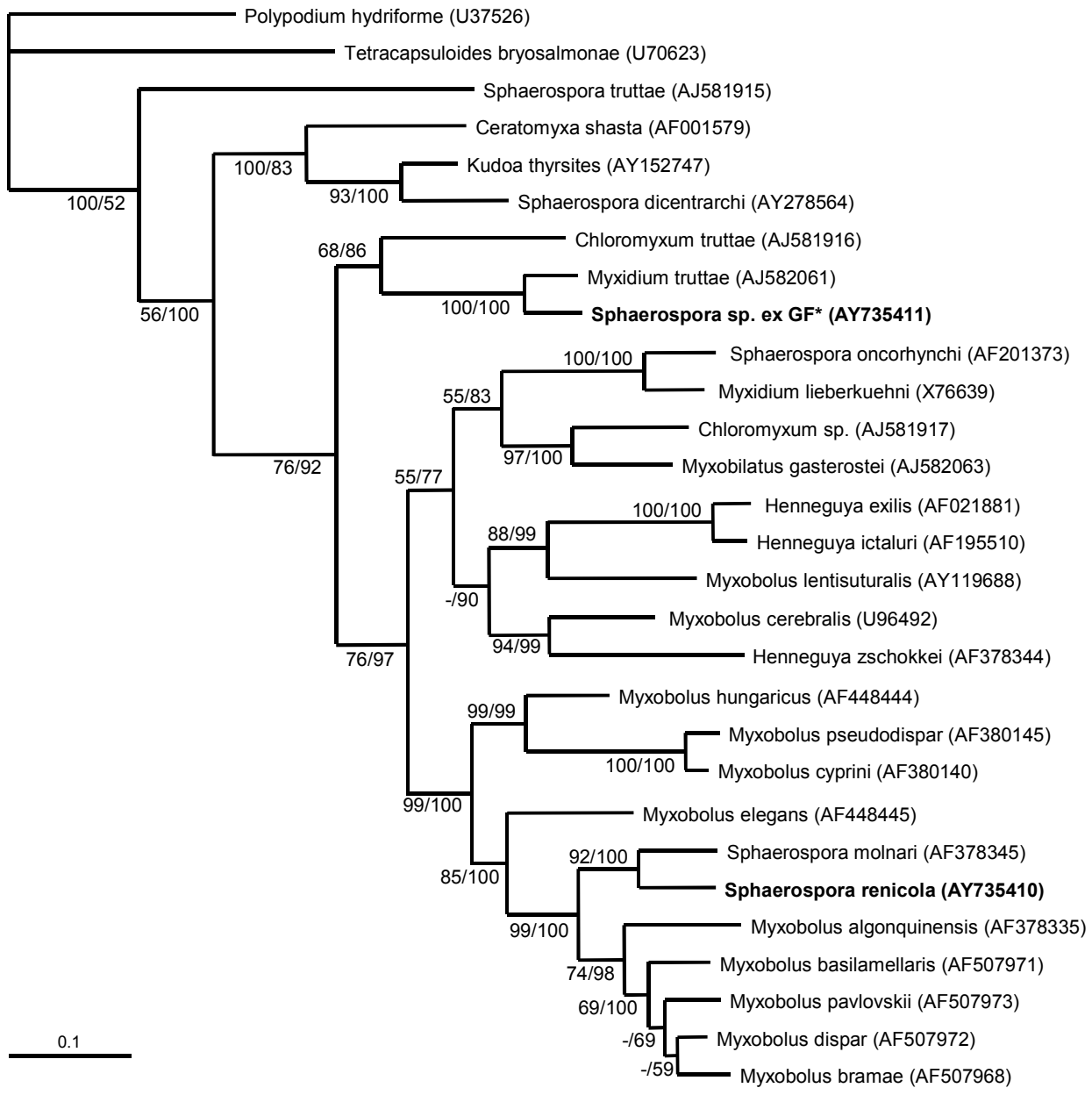

Fig. 2. Maximum likelihood tree of the $18 \mathrm{~S}$ rDNA sequences of myxosporeans, rooted at Polypodium hydriforme. Numbers at nodes indicate bootstrap confidence levels in percent (maximum likelihood: 100 repetitions, Tv/Ts 1:2; distance matrix method: 1000 repetitions). GenBank accession numbers are in parentheses. The scale bar indicates a branch length of 0.1 inferred substitutions per site. *GF: goldfish

Phylogenetic analyses were based on the final, edited alignment that was $1361 \mathrm{bp}$ in length and contained 29 myxosporean species. Interestingly, the two Sphaerospora species sequenced newly occupied distant places on phylogenetic trees (Fig. 2). The species most closely related to $S$. renicola was $S$. molnari (AF378345) with $81.8 \%$ identity in the 1413 bp sequences. They clustered with high bootstrap values to the group containing gill-infecting Myxobolus species. Sphaerospora sp. from goldfish was the most similar to Myxidium truttae (AJ582061) and 88.4\% genetic identity was obtained on 1349 bp. This sub-clade, 
supported by a high bootstrap value, was found close to other coelozoic freshwater parasites like Chloromyxum truttae (AJ581916). Distance matrix analysis confirmed the clustering pattern of maximum likelihood analysis, in several cases with different bootstrap values (Fig. 2).

In spite of the morphological similarity, Sphaerospora species occupied very different positions on the phylogenetic tree. Within the genus Sphaerospora, S. truttae was the closest to the outgroup, and its similarity to other Sphaerospora species was less than $40 \%$. The differences in $18 \mathrm{~S}$ rDNA sequences are summarised in Table 3.

Table 3

Percentage of base pair identities of 18S rDNA sequences obtained from Sphaerospora species used for phylogenetic analysis (on the basis of a $960 \mathrm{bp}$ long, unedited alignment). S trut: Sphaerospora truttae, S dicent: S. dicentrarchi, S sp-GF: Sphaerospora sp. from goldfish, S onco: S. oncorhynchi, S ren: S. renicola, S mol: S. molnari

\begin{tabular}{lcrrrrr}
\hline & S trut & S dicent & S sp-GF & S onco & S ren & S mol \\
\hline S trut & \multirow{2}{*}{100.0} & 31.3 & 36.7 & 39.0 & 35.5 & 36.4 \\
S dicent & & 100.0 & 52.1 & 51.6 & 53.0 & 50.4 \\
S sp-GF & & & 100.0 & 61.8 & 58.1 & 57.4 \\
S onco & & & & 100.0 & 66.6 & 64.2 \\
S ren & & & & & 100.0 & 79.6 \\
S mol & & & & & & 100.0 \\
\hline
\end{tabular}

\section{Discussion}

Sphaerospora renicola previously identified by Molnár (1980b) as S. angulata Fujita, 1912 is a common parasite in intensive carp cultures in Europe. Although this species has been described from common carp, it was indistinguishable morphologically from Sphaerospora sp. developing in the renal tubules of goldfish. Therefore, the genetic identity of the two myxospores infecting different hosts has also been expected. This theory seemed to be confirmed by Lom and Dyková (1992) who have reported that goldfish also could become infected by $S$. renicola. The present study on $18 \mathrm{~S}$ rDNA sequences proved that in spite of the morphological similarity, these two species are genetically distinct, and they share only $71.9 \%$ identical nucleotides. Morphologically very similar species of the genus Myxobolus have already been differentiated by molecular biological methods (Andree et al., 1999; Eszterbauer, 2002). However, members of the genus Sphaerospora have not been studied genetically as intensively as other myxosporean genera, and the five Sphaerospora species, the 18S rDNA sequences of which have previously been submitted to GenBank, differed on the basis of myxospore morphology. 
Interestingly, among the clones of $S$. renicola that were sequenced in this study, one clone of an unidentified myxosporean species was determined. Since no other myxospores could be seen in squash preparations, the occurrence of this unknown sequence cannot be readily explained. The kidney of cyprinids and other advanced bony fish contains melano-macrophage centres. The general functions of these centres are detoxification and relocation of debris of damaged cells, and they also play an important role in the response of fish to infectious agents (Agius and Roberts, 2003). Thus, the kidney of cyprinids may be an 'accumulation centre' of myxosporeans, which develop in different organs of fish and may reach the kidney via the blood system [e.g. Myxobolus pseudodispar originating from muscle (Baska, 1987)]. To avoid contamination by other myxosporeans, it is important to collect samples very carefully, and to use only separated cysts for molecular biological examinations (Eszterbauer, 2004). Unfortunately, coelozoic parasites such as Sphaerospora species examined in the present study do not form cysts, and thus this collection procedure cannot be followed. Therefore, molecular cloning of amplified PCR products is necessary, especially if primers used for PCR are not species specific. Molecular cloning of samples also gives an opportunity for a more detailed examination of intraspecific variability. The majority of the clones of $S$. renicola were genetically identical, and only in three clones was a $0.07-0.21 \%$ DNA sequence difference determined. In the case of Sphaerospora sp. the difference in the nucleotide sequence was 0.07$0.14 \%$. This diversity was related to different nucleotide positions at highly conserved regions of the $18 \mathrm{~S}$ rRNA gene, therefore nucleotide differences might be caused by the infidelity of Taq DNA polymerase.

The present phylogenetic analyses have shown that the Sphaerospora species examined to date are not closely related genetically. Sphaerospora sp. from goldfish grouped with Myxidium truttae within the clade of ancient freshwater species. Their development is coelozoic in the renal tubules as in the case of most other Sphaerospora species (e.g. S. oncorhynchi, S. dicentrarchi, S. truttae), thus we interpret that the phylogenetic position of Sphaerospora sp. from goldfish reflected its site preference. $S$. renicola clustered with $S$. molnari within the clade of myxosporeans histozoic in gills. This clade contained mostly Myxobolus species, which grouped by their tissue tropism as previously reported by Eszterbauer (2004). The phylogenetic position of S. renicola, which is a typical coelozoic parasite, might suggest that coelozoic development as an ancestral feature first disappeared and/or was replaced by histozoic development and at a later point of evolution this feature re-appeared within the clade of myxosporeans histozoic in gills.

The positions of the six Sphaerospora species involved in phylogenetic analyses showed that the morphology of myxospores does not correlate with their genetic relationship. Kent et al. (2001) suggested that most of the myxosporean genera studied up to that time (e.g. the genera Myxobolus, Henneguya, 
Myxidium) were para- or polyphyletic, and the taxa cluster by development and tissue tropism rather than by spore morphology. Although in Kent's phylogenetic analyses, only two Sphaerospora species, $S$. oncorhynchi and $S$. molnari have been used, their clustering was similar to that found in the present study. We also studied the phylogeny of Sphaerospora species in relation with their geographical locations and fish hosts. These six species originated from different locations (Canada, Hungary, Japan, UK, USA) and different hosts (mostly salmonids and cyprinids), but no correlations were found to their phylogenetic positions.

The phylogenetic relationships observed among Sphaerospora species seem to clearly confirm that this genus is polyphyletic. Genetic study of additional Sphaerospora species is needed to define the different factors influencing the evolution of this genus.

\section{Acknowledgements}

The authors thank Dr. Kálmán Molnár for his help in the collection of Sphaerospora renicola and for his useful advice during the preparation of manuscript. This work was supported by the Hungarian Scientific Research Fund (OTKA) grants No. F045908 and T042464, and by the programme entitled 'The quality development of the biological and technological bases of the Hungarian fishing sector', 4/03/2001.

\section{References}

Agius, C. and Roberts, R. J. (2003): Melano-macrophage centres and their role in fish pathology. J. Fish Dis. 26, 499-509.

Al-Samman, A., Molnár, K., Székely, Cs. and Reiczigel, J. (2003): Reno-, hepato- and splenomegaly of common carp fingerlings (Cyprinus carpio L.) diseased in swimbladder inflammation caused by Sphaerospora renicola Dyková et Lom, 1982. Acta Vet. Hung. 51, 321-329.

Andree, K. B., Székely, Cs., Molnár, K., Gresoviac, S. J. and Hedrick, R. P. (1999): Relationships among members of the genus Myxobolus (Myxozoa: Bivalvulida) based on small subunit ribosomal DNA sequences. J. Parasitol. 85, 68-74.

Baska, F. (1987): Histological studies on the development of Myxobolus pseudodispar Gorbunova, 1936 in the roach (Rutilus rutilus). Acta Vet. Hung. 35, 251-257.

Corpet, F. (1988): Multiple sequence alignment with hierarchical clustering. Nucleic Acids Res. 16, 10881-10890.

Csaba, Gy. (1976): An unidentifiable extracellular sporozoan parasite from the blood of the carp. Parasitol. Hung. 9, 21-24.

Dyková, I. and Lom, J. (1982): Sphaerospora renicola n. sp., a myxosporean from carp kidney, and its pathogenicity. Z. Parasitenkd. 68, 259-268.

Dyková, I. and Lom, J. (1988): Review of pathogenic myxosporeans in intensive culture of carp (Cyprinus carpio) in Europe. Folia Parasitol. 35, 289-307.

Eszterbauer, E. (2002): Molecular biology can differentiate morphologically indistinguishable myxosporean species: Myxobolus elegans and M. hungaricus. Acta Vet. Hung. 50, 59-62.

Eszterbauer, E. (2004): Genetic relationship among gill-infecting Myxobolus species (Myxosporea) of cyprinids: molecular evidence of importance of tissue-specificity. Dis. Aquat. Org. 58, $35-40$. 
Felsenstein, J. (1997): PHYLIP-Phylogeny inference package v3.6a. Distributed by the University of Washington, Seattle, USA.

Holzer, A. S., Sommerville, C. and Wootten, R. (2003a): Tracing the route of Sphaerospora truttae from the entry locus to the target organ of the host, Salmo salar L., using an optimised and specific in situ hybridisation technique. J. Fish Dis. 26, 647-655.

Holzer, A. S., Sommerville, C. and Wootten, R. (2003b): Communities of myxosporeans and actinosporeans in a Scottish highland stream and their molecular relationships based on $18 \mathrm{~S}$ rDNA sequences. 11th International Conference of the European Association of Fish Pathologists, 21-26 September 2003, Malta. Abstract No. P-070.

Kent, M. L., Andree, K. B., Bartholomew, J. L., El-Matbouli, M., Desser, S. S., Delvin, R. H., Feist, S. W., Hedrick, R. P., Hoffmann, R. W., Khattra, J., Hallett, S. L., Lester, R. J. G., Longshaw, M., Palenzula, O., Siddall, M. E., Xiao, C. (2001): Recent advances in our knowledge of the Myxozoa. J. Eukaryot. Microbiol. 48, 395-413.

Kovács-Gayer, E., Csaba, Gy., Békési, L., Bucsek, M., Szakolczai, J. and Molnár, K. (1982): Studies on the protozoan etiology of swimbladder inflammation in common carp fry. Bull. Eur. Ass. Fish. Pathol. 2, 22-24.

Körting, W. (1982): Protozoan parasites associated with swimbladder inflammation in young carp. Bull. Eur. Assoc. Fish Pathol. 2, 25-28.

Lom, J. and Dyková, I. (1992): Protozoan Parasites of Fishes. Elsevier, New York. p. 315.

Molnár, K. (1980a): Renal sphaerosporosis in the common carp Cyprinus carpio L. J. Fish Dis. 3, 11-19.

Molnár, K. (1980b): 'Sphaerosporosis', a new kidney disease of the common carp. Fish Dis. Third COPRAQ Session. Springer-Verlag, Berlin, Heidelberg, New York. pp. 157-164.

Molnár, K., Eszterbauer, E., Székely, Cs., Dán, Á. and Harrach, B. (2002): Morphological and molecular biological studies on intramuscular Myxobolus spp. of cyprinid fish. J. Fish Dis. 25, 643-652.

Odening, K. (1987): Sphaerospora renicola (Myxosporidia), der Erreger der protozoären Schwimmblasenentzündung des Jungkarpfens (renicola-Sphaerosporose). Angew. Parasitol. 28, 1-16.

Staden, R. (1996): The Staden Sequence Analysis Package. Mol. Biotech. 5, 233-241. 